
\title{
25 Research Suare \\ Effect of Residue Type on Extractable Organic and Microbial Biomass Carbon Fractions Under Long-Term Soil Fertilization
}

\section{Ninghui Xie}

Shenyang Agricultural University

\section{Sean Michael Schaeffer}

Department of Biosystems Engineering and Soil Science, University of Tennessee

\section{Tingting An}

Shenyang Agricultural University

\section{Yingde Xu}

Shenyang Agricultural University

\section{Shuangyi Li}

Shenyang Agricultural University

\section{Liangjie Sun}

Shenyang Agricultural University

Jingkuan Wang ( $\nabla$ jkwang@syau.edu.cn )

Shenyang Agricultural University

\section{Research Article}

Keywords: maize residue, soil fertilization, 13C-labeling technique, extractable organic carbon, microbial biomass carbon

Posted Date: March 23rd, 2021

DOl: https://doi.org/10.21203/rs.3.rs-341230/v1

License: (1) This work is licensed under a Creative Commons Attribution 4.0 International License. Read Full License 


\section{Abstract}

The labile organic carbon (C) pool plays a vital role in soil biogeochemical transformation and can be used as a sensitive indicator of the response of soil quality to agricultural practice. However, little is known about how residue type and soil fertilization affect the incorporation of residue $C$ into labile organic $C$ pools. A 360-day laboratory incubation was conducted with the addition of ${ }^{13} \mathrm{C}$-labeled maize residues (root, stem and leaf) to unfertilized and organic-fertilized soils. A greater contribution of residue $C$ to extractable organic $C$ (EOC, $7.2 \%)$ was observed in the unfertilized soil than that in the organic-fertilized soil (6.0\%). The contribution of residue $\mathrm{C}$ to microbial biomass C (MBC) was $20 \%-50 \%$ in the organic-fertilized soil, but only $10 \%-30 \%$ in the unfertilized soil. This suggests that, in organic-fertilized soil, there is accelerated transformation of residue $\mathrm{C}$ into microbial biomass and a higher capacity for residue $\mathrm{C}$ stabilization through greater, or more efficient anabolism.

Moreover, the distribution of leaf $\mathrm{C}$ into $\mathrm{MBC}$ was higher than that from root and stem in the unfertilized soil, whereas more root $\mathrm{C}$ entered to $\mathrm{EOC}$ and $\mathrm{MBC}$ than from stem and leaf in the organic-fertilized soil. This shows that maize root can also be involved in microbial assimilation, but it depends on the initial soil nutrition. Overall, these findings deepen our understanding of the mechanisms of microbe-mediated $\mathrm{C}$ transformation processes, and provide relevant insights into the capture and incorporation of plant residue $\mathrm{C}$ into labile organic $\mathrm{C}$ pools driven by residue type and soil fertilization.

\section{Introduction}

Soil organic carbon (SOC) sequestration is critical for agriculture and the environment, particularly in soil health and food security (Lal, 2004). SOC stocks are governed by the balance between carbon (C) input and output, and strongly affected by soil management practices (Paustian et al. 2000). Adoption of plant residue retention methods are essential to maintain, or improve SOC content and the sustainability of agricultural systems (Lal 2004; Diacono et al. 2010). However, SOC dynamics induced by plant residue retention generally occurs slowly since the total SOC pool is too large to be affected in the short-term (Salinas-Garcia et al. 1997; Ding et al. 2012). In this context, SOC fractions with relatively higher turnover rates and/or reactivity can be used to quantify the effect of agricultural management on soil quality (Silveira et al. 2008). Specifically, soluble organic $\mathrm{C}$ and microbial biomass $\mathrm{C}$ (MBC) fractions respond more quickly to soil management activities than other $\mathrm{C}$ pools (Nieder et al. 2008; Lehmann and Kleber 2015).

Plant residues provide available substrate for soil microorganisms (Shahbaz et al. 2017a), and in turn play an important role in microbe-mediated biogeochemical processes (Ge et al. 2015; Haubensak et al. 2002). Plant residue can be preferentially utilized by microorganisms for biomass production during microbial growth processes (Liang et al., 2017). Microorganisms solubilize plant-derived $C$ through depolymerization by extracellular enzymes, and any net increase in the soluble $\mathrm{C}$ fraction is driven by microbial death, exudation, or a decrease in microbial assimilation (Burns et al. 2013). Generally, the dynamics of microbial utilization of residue $\mathrm{C}$ and stabilization, for example, relative abundances of soluble organic $\mathrm{C}$ and $\mathrm{MBC}$, are mainly mediated by plant residue quality (Chen et al. 2009; Prescott 2010; Liang et al., 2017). In the traditional view, root residue is relatively recalcitrant, and has a slower decomposition rate, thus more root $\mathrm{C}$ is incorporated into the stable SOC fractions than that from stem and leaf residues (Lian et al. 2016; Johnson et al. 2014). However, a prevailing counter hypothesis proposes that labile $\mathrm{C}$ compounds can contribute more to long-term soil $\mathrm{C}$ stability than highly recalcitrant chemical compounds such as lignin (Amelung et al., 2008; Schmidt et al., 2011; 
Lehmann and Kleber 2015). This is because above-ground residues (e.g. stem and leaf residues) contain more easily degradable $\mathrm{C}$, which plays a significant role in labile organic $\mathrm{C}$ accumulation, and subsequently, may contribute more to SOC sequestration due to high microbial utilization efficiency (Don and Kalbitz 2005; Cotrufo et al. 2013, 2015). These new theories challenge our understanding of the mechanisms of how root vs. aboveground residues is involved in SOC formation. Therefore, given the important role of labile $\mathrm{C}$ in the SOC accumulation, it is necessary to strengthen our knowledge of the impacts of plant residue type on the microbial assimilation of exogenous $\mathrm{C}$ and the dynamics of soil labile $\mathrm{C}$, i.e., soluble organic $\mathrm{C}$ and $\mathrm{MBC}$.

Soil fertilization and total SOC are important factors controlling microbial assimilation of plant residue (Wang et al. 2014; Zhu et al. 2016; Marschner et al. 2001). The dynamics and distribution of residue $\mathrm{C}$ in soil depends upon soil fertility under long-term soil fertilization regimes because more residue $C$ tends to accumulate in MBC in low fertility soil compared with high fertility soil (An et al. 2015a). However, the combined applications of plant residues (leaf, stems and roots) in soils may differentially affect proportional labile organic $\mathrm{C}$ accumulation, resulting in differences in residue $\mathrm{C}$ accumulation in the total SOC pool of the soils with different levels of SOC (Lian et al. 2016). Because microbial competition for residue $C$ depends upon initial soil properties (An et al. 2015a), the application of organic fertilizers, which enhance soil fertility (Macci et al. 2013; Jin et al. 2018), is expected to affect microbial utilization of plant residues. In general, the addition of residue $C$ to soil enhances soil labile organic pools (An et al. 2015a), but the additions of different quality residues in soils with different levels of SOC and nutrients determine its accumulation (Singh et al. 2007; Fang et al. 2018). The effect of soil fertilization on the incorporation of different types of maize residues into labile $\mathrm{C}$ pools has received far less attention.

The objectives of our research were: (1) to quantify the contribution of different types of maize residue to soluble organic $C$, measured as extractable organic $C$ (EOC), and MBC and (2) to determine the differences in distribution and utilization of residue $\mathrm{C}$ in long-term soil fertilization among residue types. We added the ${ }^{13} \mathrm{C}$ labeled maize residues (leaf, stem and root) to unfertilized and organic-fertilized soils and incubated the soils for 360 days. The percentages of different residue $\mathrm{C}$ in EOC and MBC fractions were determined. The incubation study was designed to test the following hypotheses: (1) plant residue addition would increase the labile organic $C$, with its magnitude depending on the residue types, i.e., more aboveground residue $C$ would be incorporated in labile organic $C$ than root residue $\mathrm{C}$; (2) soil fertilization would regulate the distribution of plant residue $C$ in $E O C$ and $M B C$, and the greater distribution of residue $C$ in labile organic $C$ would be in unfertilized soil because of $\mathrm{C}$ deficiency than organic-fertilized soil.

\section{Materials And Methods}

\section{Experimental site and soil sampling}

Soil samples were collected from a long-term fertilization experiment station $\left(41^{\circ} 49^{\prime} \mathrm{N}, 123^{\circ} 34^{\prime} \mathrm{E}\right)$ that was established in 1987 at Shenyang Agricultural University, Liaoning, China. This region is characterized by a typical continental monsoon climate, with annual mean temperature of $7.9^{\circ} \mathrm{C}$ and annual mean precipitation of $705 \mathrm{~mm}$. The soil type is Brown Earth according to the Chinese Soil Taxonomy (a Hapli-Udic Alfisol according to the USDA Taxonomy, Soil Survey Staff, 1999). The cropping system is monoculture maize which 
is sown in early May and harvested in early October each year. A detailed description of this site was given by An et al. (2015b).

Field plots with two fertility levels were selected for this study: (1) no fertilizer application (unfertilized soil); (2) application of composted swine manure (270 kg N ha $\mathrm{y}^{-1}$ ) for more than 27 years (organic-fertilized soil). The compost contained $150 \mathrm{~g} \mathrm{~kg}^{-1}$ total organic $\mathrm{C} ; 10 \mathrm{~g} \mathrm{~kg}^{-1}$ total $\mathrm{N} ; 10 \mathrm{~g} \mathrm{~kg}^{-1} \mathrm{P}_{2} \mathrm{O}_{5}$ and $4 \mathrm{~g} \mathrm{~kg}^{-1} \mathrm{~K}_{2} \mathrm{O}$ on a dry weight basis (An et al. 2015a). In each plot, a total of five samples were randomly collected, and then fully mixed to form one composite soil sample to represent each experimental plot. Soil samples (0-20 cm depth) were collected in November, 2014, and all visible crop roots and debris were removed, then all the soil samples were sieved $(2 \mathrm{~mm})$ and air-dried for the subsequent incubation experiment. The main soil properties of the soil samples are shown in Table 1.

Table 1

Basic characteristics of soil samples in long-term fertilization of soils (in 2014)

\begin{tabular}{|c|c|c|c|c|c|c|c|c|c|}
\hline $\begin{array}{l}\text { Soil } \\
\text { fertilization }\end{array}$ & $\begin{array}{l}\text { Total } \\
\text { soil } \\
\text { organic } \\
\text { carbon } \\
\\
\left(\mathrm{g} \mathrm{kg}^{-}\right. \\
\left.{ }^{1}\right)\end{array}$ & $\begin{array}{l}\delta^{13} C \\
(\% \circ)\end{array}$ & $\begin{array}{l}\text { Total } \\
\text { nitrogen } \\
(\mathrm{N}, \mathrm{g} \\
\left.\mathrm{kg}^{-1}\right)\end{array}$ & $\begin{array}{l}\text { Total } \\
\text { phosphorus } \\
\left(\mathrm{P}, \mathrm{g} \mathrm{kg}^{-1}\right)\end{array}$ & $\mathrm{C} / \mathrm{N}$ & $\mathrm{C} / \mathrm{P}$ & $\begin{array}{l}\text { Clay } \\
(\%)\end{array}$ & $\begin{array}{l}\mathrm{pH} \\
\left(\mathrm{H}_{2} \mathrm{O}\right)\end{array}$ & $\begin{array}{l}\text { Microbial } \\
\text { biomass } \\
\text { carbon } \\
\text { (mg kg- } \\
\text { 1) }\end{array}$ \\
\hline Unfertilized & $\begin{array}{l}10.10 \\
\pm 0.15\end{array}$ & $\begin{array}{l}-17.88 \\
\pm 0.15\end{array}$ & $\begin{array}{l}1.10 \pm \\
0.06\end{array}$ & $4.92 \pm 0.24$ & $\begin{array}{l}8.91 \\
\pm \\
0.13\end{array}$ & $\begin{array}{l}2.05 \\
\pm \\
0.63^{*}\end{array}$ & $\begin{array}{l}17.30 \\
\pm 0.13\end{array}$ & $\begin{array}{l}6.11 \\
\pm \\
0.23\end{array}$ & $\begin{array}{l}117.69 \pm \\
3.25\end{array}$ \\
\hline $\begin{array}{l}\text { Organic- } \\
\text { fertilized }\end{array}$ & $\begin{array}{l}17.80 \\
\pm 0.16^{*}\end{array}$ & $\begin{array}{l}-19.45 \\
\pm \\
0.17^{*}\end{array}$ & $\begin{array}{l}2.20 \pm \\
0.02^{*}\end{array}$ & $\begin{array}{l}22.77 \pm \\
2.48^{*}\end{array}$ & $\begin{array}{l}8.10 \\
\pm \\
0.11\end{array}$ & $\begin{array}{l}0.78 \\
\pm \\
0.06\end{array}$ & $\begin{array}{l}18.94 \\
\pm 0.14\end{array}$ & $\begin{array}{l}6.31 \\
\pm \\
0.27\end{array}$ & $\begin{array}{l}163.54 \pm \\
5.23^{*}\end{array}$ \\
\hline
\end{tabular}

a Unfertilized: Iong-term no fertilization soil; Organic-fertilized: long-term organic manure fertilization soil.

${ }^{b}$ Stars show the significant differences $(P<0.05)$ between soil fertilizations at the same indicator.

\section{Preparation of ${ }^{13} \mathrm{C}$-labeled maize residue}

Root, stem and leaf residue were obtained from fully matured maize plants that had been pulse-labeled with ${ }^{13} \mathrm{CO}_{2}(98$ atom \%) for six times across the whole growth stages in 2014 (An et al. 2015b). The aboveground plant was cut at the root base and then stem and leaf residues were carefully collected. The main and lateral roots were gently separated from soil and then washed off the adhering soil with tap water. All the sampled residues were oven-dried at $70{ }^{\circ} \mathrm{C}$ for $12 \mathrm{~h}$. Five plants (root, stem, and leaf, respectively) were randomly selected from all the labeling maize plants and then chopped $5 \mathrm{~mm}$ segments. After that, the residues were selected by the quartering methods and then ground into less than $0.5-\mathrm{mm}$ segments. Root residue contained $400 \mathrm{~g} \mathrm{~kg}^{-1}$ total organic $\mathrm{C}, 12.6 \mathrm{~g} \mathrm{~kg}^{-1}$ total $\mathrm{N}, 394 \% \delta^{13} \mathrm{C}$ value, and $\mathrm{C} / \mathrm{N}$ ratio of 32 . Stem residue contained 
$440 \mathrm{~g} \mathrm{~kg}^{-1}$ total organic $\mathrm{C}, 14.5 \mathrm{~g} \mathrm{~kg}^{-1}$ total $\mathrm{N}, 696 \%$ o $\delta^{13} \mathrm{C}$ value, and $\mathrm{C} / \mathrm{N}$ ratio of 30 . Leaf residue contained $421 \mathrm{~g} \mathrm{~kg}^{-1}$ total organic $\mathrm{C}, 12.7 \mathrm{~g} \mathrm{~kg}^{-1}$ total $\mathrm{N}, 662 \%$ o $\delta^{13} \mathrm{C}$ value, and $\mathrm{C} / \mathrm{N}$ ratio of 33 .

\section{Incubation experiment}

Air-dried soil sample (120 g) was weighted into $500 \mathrm{ml}$ incubation vessels. Soil was then pre-incubated at $35 \%$ of its water holding capacity (WHC) at $25^{\circ} \mathrm{C}$ for 7 days, because sieving affects the availability of soil organic matter (SOM) for soil microorganisms (An et al. 2015a). The pre-incubated soil samples were amended with root, stem and leaf residues (1\% of oven-dried soil weight), respectively. No amendment was applied in the control treatment. The added residues were thoroughly mixed with incubated soil. The glass vessels were sealed with parafilm, and several tiny holes were drilled in the parafilm in order to allow gas going through while retarding soil water evaporation (Wang et al. 2014). Soil samples were incubated at $25^{\circ} \mathrm{C}$ at $60 \%$ WHC for 360 days under darkness. Periodically, the vessels were weighed, and the soil water content was maintained at the original soil moisture level throughout the incubation period by supplementation with distilled water. Three replicates of each treatment were randomly and destructively sampled on the 1st, 7th, 28th, 56th, 180th and 360th day after incubation. A part of the sample was stored at $4{ }^{\circ} \mathrm{C}$ for $\mathrm{EOC}$ and $\mathrm{MBC}$ analysis. While the other part was air-dried, ground through $0.15 \mathrm{~mm}$ sieve and analyzed for SOC content and $\delta^{13} \mathrm{C}$ value.

\section{$\mathrm{MBC}$ and EOC determination}

MBC was determined using chloroform-fumigation extraction (Vance et al. 1987). Briefly, fresh soil samples (equivalent to $10 \mathrm{~g}$ oven-dried soil) were fumigated with purified $\mathrm{CHCl}_{3}$ for $24 \mathrm{~h}$ in the dark at $25^{\circ} \mathrm{C}$. After fumigation, the soil samples were extracted with $0.5 \mathrm{M} \mathrm{K}_{2} \mathrm{SO}_{4}$ at 1:4 soil: solution ratio. An equivalent amount of non-fumigated soil was also extracted when fumigation commenced. The organic $\mathrm{C}$ of the non-fumigated extract was the EOC (Schaeffer et al. 2013). The organic C content of soil extract was determined with the Total Organic Carbon Analyzer (Elementar High TOC II, Germany). MBC was calculated as the difference in organic C content between fumigated and non-fumigated soil extracts with a correction factor $\left(k_{E C}\right)$ of 0.45 (Wu et al. 1990). All $\mathrm{K}_{2} \mathrm{SO}_{4}$-extract aliquots $(20 \mathrm{ml})$ were freeze-dried for the determination of ${ }^{13} \mathrm{C}$ abundances.

\section{Isotopic $\mathrm{C}$ analysis and calculation}

Analyses of the organic $\mathrm{C}$ contents and $\delta^{13} \mathrm{C}$ values in soil were conducted in an elemental analyzer (Elementar Vario PYRO cube, Germany) coupled to an isotope ratio mass spectrometer (IsoPrime 100 Isotope Ratio Mass Spectrometer, Germany). $\delta^{13} \mathrm{C}$ values of $\mathrm{K}_{2} \mathrm{SO}_{4}$ extract samples were also determined in the same way. The $\delta^{13} \mathrm{C}$ value was expressed in parts per mil (\%o) relative to the international standard Pee Dee Belemnite (PDB) (Werner and Brand 2001).

The $\delta^{13} \mathrm{C}$ value of $\mathrm{MBC}\left(\delta^{13} \mathrm{C}_{\mathrm{MBC}}, \%\right)$ was calculated as follows:

$$
\delta^{13} C_{M B C}=\left[\left(C_{F} \times \delta^{13} C_{F}\right)-\left(C_{N^{F}} \times \delta^{13} C_{N F}\right)\right] /\left(C_{F}-C_{N F}\right)
$$

where $C_{F}$ and $\delta^{13} C_{F}$ are the total organic $C$ content (mg kg soil ${ }^{-1}$ ) and $\delta^{13} \mathrm{C}$ value (\%o) in the fumigated extracts, respectively, and $\mathrm{C}_{\mathrm{NF}}$ and $\delta^{13} \mathrm{C}_{N F}$ are the total organic $\mathrm{C}$ content (mg kg soil ${ }^{-1}$ ) and $\delta^{13} \mathrm{C}$ value (\%o) in 
the non-fumigated extracts, respectively.

The percentage $(f, \%)$ of maize residue $C$ in MBC and EOC was calculated according to De Troyer et al. (2011):

$$
f=\left(\delta^{13} C_{\text {sample }}-\delta^{13} C_{\text {control }}\right) \times 100 /\left(\delta^{13} C_{\text {residite } 0}-\delta^{13} C_{\text {control }}\right)
$$

where $\delta^{13} \mathrm{C}_{\text {sample }}$ is the $\delta^{13} \mathrm{C}$ value (\%) of $\mathrm{C}$ pool in soil sample treated with maize residue, $\delta^{13} \mathrm{C}_{\text {control }}$ is the $\delta^{13} \mathrm{C}$ value (\%o) of $\mathrm{C}$ pool do the corresponding soil sample without maize residue addition and $\delta^{13} \mathrm{C}_{\text {residueo }}$ is the $\delta^{13} \mathrm{C}$ value of the applied maize residue.

The content of $\mathrm{C}$ pool derived from residue $\mathrm{C}\left(\mathrm{C}_{\text {residue }}\right)$ was calculated with the following equation (Blaud et al. 2012):

$$
C_{\text {residue }}=C_{\text {sanple }} \times f
$$

where $\mathrm{C}_{\text {sample }}$ is the total content of $\mathrm{C}$ pool in $\mathrm{EOC}$ and $\mathrm{MBC}$.

Repeated measures analysis was performed for all data over time, using a linear mixed model consisting of fixed effects of soil fertilization (unfertilized and organic-fertilized soil), plant residue types (maize root, stem and leaf), and time and their associated interaction, and random effects of replicates and replicates by time. All repeated measurements satisfy the assumption of sphericity. To allow for correlation between repeated measures on the same treatment, a first-order antedependence correlation model was assumed for the residuals within a plot (Fang et al., 2018). Differences between soil fertilizations were assessed by paired T-test. All statistical analyses were performed with IBM SPSS 19.0 (IBM, USA) software package with significant differences at $P<0.05$ level. Graphs were drawn using Origin 8 (Origin Lab, USA).

\section{Results}

\section{Contribution of maize residue $\mathrm{C}$ to EOC}

Soil fertilization and residue type significantly affected $(P<0.05)$ the contents of EOC (Table 2$)$. EOC decreased from $241 \mathrm{mg} \mathrm{kg}^{-1}$ soil to $138 \mathrm{mg} \mathrm{kg}^{-1}$ soil (Fig. 1a and b) during the incubation time. And it was $1-2$ times higher in the organic-fertilized soil than that in the unfertilized soil treated with residues. The content of EOC in the unfertilized soil treated with root residue was lower than those treated with stem and leaf residues during the whole incubation. However, the opposite trend was observed in the organic-fertilized soil treated with residues after 56 days. At the end of incubation (360th day), the EOC content in the organic-fertilized soil added with root residue was about $30 \%$ higher than those of stem and leaf residues. 
Table 2

Statistical significance ( $P$ values) of the fixed terms of soil fertilization (F; unfertilized soil and organic-fertilized soil), residue type (R; root, stem and leaf), and/or time $(T)$ and their associated interaction on the dependent variables tested.

\begin{tabular}{|c|c|c|c|c|c|c|c|c|}
\hline Factor & EOC & $\begin{array}{l}{ }^{13} \mathrm{C}- \\
\mathrm{EOC}\end{array}$ & MBC & $\begin{array}{l}{ }^{13} \mathrm{C}- \\
\mathrm{MBC}\end{array}$ & $\begin{array}{l}{ }^{13} \mathrm{C} \text {-EOC/ } \\
{ }^{13} \text { CresidueO }\end{array}$ & $\begin{array}{l}{ }^{13} \mathrm{C}-\mathrm{MBC} / \\
{ }^{13} \text { Cresidueo }\end{array}$ & $\begin{array}{l}{ }^{13} \mathrm{C}- \\
\mathrm{EOC} / \\
\text { EOC }\end{array}$ & $\begin{array}{l}{ }^{13} \mathrm{C}- \\
\mathrm{MBC} \\
\mathrm{MBC}\end{array}$ \\
\hline $\begin{array}{l}\text { Soil fertilization } \\
\text { (F) }\end{array}$ & $\begin{array}{l}P< \\
0.001\end{array}$ & $\begin{array}{l}P< \\
0.001\end{array}$ & $\begin{array}{l}P< \\
0.001\end{array}$ & $\begin{array}{l}P< \\
0.001\end{array}$ & $P<0.001$ & $P<0.001$ & $\begin{array}{l}P< \\
0.001\end{array}$ & $\begin{array}{l}P< \\
0.001\end{array}$ \\
\hline $\begin{array}{l}\text { Residue type } \\
\text { (R) }\end{array}$ & $\begin{array}{l}P< \\
0.001\end{array}$ & $\begin{array}{l}P< \\
0.001\end{array}$ & 0.047 & 0.002 & $P<0.001$ & 0.04 & $\begin{array}{l}P< \\
0.001\end{array}$ & 0.044 \\
\hline $\begin{array}{l}\text { Time } \\
(\mathrm{T})\end{array}$ & $\begin{array}{l}P< \\
0.001\end{array}$ & 0.011 & $\begin{array}{l}P< \\
0.001\end{array}$ & $\begin{array}{l}P< \\
0.001\end{array}$ & $P<0.001$ & $P<0.001$ & $\begin{array}{l}P< \\
0.001\end{array}$ & $\begin{array}{l}P< \\
0.001\end{array}$ \\
\hline $\mathrm{F} \times \mathrm{R}$ & $\begin{array}{l}P< \\
0.001\end{array}$ & 0.001 & 0.039 & $\begin{array}{l}P< \\
0.001\end{array}$ & 0.001 & $P<0.001$ & 0.12 & $\begin{array}{l}P< \\
0.001\end{array}$ \\
\hline $\mathrm{F} \times \mathrm{T}$ & $\begin{array}{l}P< \\
0.001\end{array}$ & $\begin{array}{l}P< \\
0.001\end{array}$ & $\begin{array}{l}P< \\
0.001\end{array}$ & $\begin{array}{l}P< \\
0.001\end{array}$ & 0.002 & $P<0.001$ & $\begin{array}{l}P< \\
0.001\end{array}$ & $\begin{array}{l}P< \\
0.001\end{array}$ \\
\hline $\mathrm{R} \times \mathrm{T}$ & $\begin{array}{l}P< \\
0.001\end{array}$ & $\begin{array}{l}P< \\
0.001\end{array}$ & 0.002 & $\begin{array}{l}P< \\
0.001\end{array}$ & $P<0.001$ & 0.07 & $\begin{array}{l}P< \\
0.001\end{array}$ & 0.001 \\
\hline $\mathrm{F} \times \mathrm{R} \times \mathrm{T}$ & 0.054 & 0.043 & 0.004 & 0.001 & $P<0.001$ & 0.018 & $\begin{array}{l}P< \\
0.001\end{array}$ & $\begin{array}{l}P< \\
0.001\end{array}$ \\
\hline
\end{tabular}

a EOC, total extractable organic carbon; ${ }^{13} \mathrm{C}-\mathrm{EOC}$, EOC derived from residue C; $\mathrm{MBC}$, total microbial biomass carbon; ${ }^{13} \mathrm{C}-\mathrm{MBC}, \mathrm{MBC}$ derived from residue $\mathrm{C} ;{ }^{13} \mathrm{C}$-EOC $/{ }^{13} \mathrm{C}$ residue0, percentage of ${ }^{13} \mathrm{C}$-EOC in initial content of $\mathrm{C}$ in the residue; ${ }^{13} \mathrm{C}-\mathrm{MBC} /{ }^{13} \mathrm{Cresidue}$, percentage of ${ }^{13} \mathrm{C}-\mathrm{MBC}$ in initial content of $\mathrm{C}$ in the residue; ${ }^{13} \mathrm{C}$ EOC/EOC, percentage of ${ }^{13} \mathrm{C}-\mathrm{EOC}$ in $\mathrm{EOC} ;{ }^{13} \mathrm{C}-\mathrm{MBC} / \mathrm{MBC}$, percentage of ${ }^{13} \mathrm{C}-\mathrm{MBC}$ in $\mathrm{MBC}$.

The contribution of root and stem-derived residue $\mathrm{C}$ to EOC decreased with the incubation time in different fertilizer treatments (Table 3). At the end of incubation, a greater contribution of residue $\mathrm{C}$ to EOC was seen in the unfertilized soil compared with organic-fertilized soil. The contribution of residue-derived $\mathrm{C}$ to EOC was less than $12 \%$ in the unfertilized soil (Table 3$)$, with the highest content of EOC derived from residue $\left({ }^{13} \mathrm{C}\right.$-EOC) (an average of $27 \mathrm{mg} \mathrm{kg}^{-1}$ soil) (Fig. 2a and b), on the first day. The ${ }^{13} \mathrm{C}$-EOC value decreased sharply to $11 \mathrm{mg} \mathrm{kg}$ 1 soil on the 28th day, and then slowly decreased in the unfertilized soil treated with residues till the end of incubation. A greater contribution of residue $\mathrm{C}$ to EOC treated with root was observed in the unfertilized than those in stem and leaf residues during the whole incubation (Table 3 ). The peak value of ${ }^{13} \mathrm{C}$-EOC in the organic-fertilized soil, accounting for about $9.0 \%$ of EOC, occurred on the 28th day for the three residues (Table 3). After 180 days, the contribution of residue $\mathrm{C}$ derived from root to $\mathrm{EOC}(8.2 \%)$ was higher compared with residue $\mathrm{C}(4.9 \%)$ from leaf and stem in the organic-fertilized soil. 
Table 3

Relative contributions (\%) of residue carbon in extractable organic carbon and microbial biomass carbon in long-term fertilization of soils added with maize root, steam and leaf residues, respectively

\begin{tabular}{|c|c|c|c|c|c|c|c|c|c|c|c|c|}
\hline \multirow{3}{*}{$\begin{array}{l}\text { Incubation } \\
\text { time } \\
\text { (days) }\end{array}$} & \multicolumn{6}{|c|}{ Extractable organic carbon } & \multicolumn{6}{|c|}{ Microbial biomass carbon } \\
\hline & \multicolumn{2}{|c|}{ Root residue } & \multicolumn{2}{|c|}{$\begin{array}{l}\text { Stem } \\
\text { residue }\end{array}$} & \multicolumn{2}{|c|}{$\begin{array}{l}\text { Leaf } \\
\text { residue }\end{array}$} & \multicolumn{2}{|c|}{ Root residue } & \multicolumn{2}{|c|}{ Stem residue } & \multicolumn{2}{|c|}{ Leaf residue } \\
\hline & UF & OF & UF & OF & UF & OF & UF & OF & UF & OF & UF & OF \\
\hline
\end{tabular}

\begin{tabular}{|c|c|c|c|c|c|c|c|c|c|c|c|c|}
\hline 1 & $\begin{array}{l}11.4 \\
\pm 0.9 \\
a^{*}\end{array}$ & $\begin{array}{l}8.7 \\
\pm \\
0.7 \\
a\end{array}$ & $\begin{array}{l}9.3 \\
\pm \\
0.8 \\
b^{*}\end{array}$ & $\begin{array}{l}7.6 \\
\pm \\
0.4 \\
b\end{array}$ & $\begin{array}{l}6.8 \\
\pm \\
0.5 \\
c^{*}\end{array}$ & $\begin{array}{l}5.7 \\
\pm \\
0.4 \\
c\end{array}$ & $\begin{array}{l}11.1 \\
\pm 1.0 \\
\mathrm{~b}\end{array}$ & $\begin{array}{l}25.0 \\
\pm 2.7 \\
a^{*}\end{array}$ & $\begin{array}{l}13.2 \\
\pm 1.4 \\
a\end{array}$ & $\begin{array}{l}20.3 \\
\pm 2.2 \\
b^{*}\end{array}$ & $\begin{array}{l}14.5 \\
\pm 1.2 \\
a\end{array}$ & $\begin{array}{l}22.2 \\
\pm 2.1 \\
a^{*}\end{array}$ \\
\hline 7 & $\begin{array}{l}7.2 \\
\pm 0.6 \\
a\end{array}$ & $\begin{array}{l}8.0 \\
\pm \\
0.4 \\
a^{*}\end{array}$ & $\begin{array}{l}7.2 \\
\pm \\
0.7 \\
a\end{array}$ & $\begin{array}{l}6.9 \\
\pm \\
0.5 \\
b\end{array}$ & $\begin{array}{l}6.3 \\
\pm \\
0.5 \\
b^{*}\end{array}$ & $\begin{array}{l}5.4 \\
\pm \\
0.5 \\
c\end{array}$ & $\begin{array}{l}19.4 \\
\pm 1.9 \\
\mathrm{~b}\end{array}$ & $\begin{array}{l}28.6 \\
\pm 2.6 \\
a^{*}\end{array}$ & $\begin{array}{l}18.9 \\
\pm 1.5 \\
b\end{array}$ & $\begin{array}{l}21.0 \\
\pm 2.0 \\
b^{*}\end{array}$ & $\begin{array}{l}22.4 \\
\pm 2.0 \\
a\end{array}$ & $\begin{array}{l}25.0 \\
\pm 2.3 \\
a^{*}\end{array}$ \\
\hline 28 & $\begin{array}{l}7.5 \\
\pm 0.5 \\
a\end{array}$ & $\begin{array}{l}8.6 \\
\pm \\
0.4 \\
a^{*}\end{array}$ & $\begin{array}{l}5.5 \\
\pm \\
0.5 \\
a\end{array}$ & $\begin{array}{l}8.9 \\
\pm \\
0.5 \\
a^{*}\end{array}$ & $\begin{array}{l}7.8 \\
\pm \\
0.5 \\
a\end{array}$ & $\begin{array}{l}9.1 \\
\pm \\
0.8 \\
\\
a^{*}\end{array}$ & $\begin{array}{l}14.1 \\
\pm 1.2 \\
b\end{array}$ & $\begin{array}{l}30.0 \\
\pm 2.8 \\
a^{*}\end{array}$ & $\begin{array}{l}15.3 \\
\pm 1.4 \\
\mathrm{~b}\end{array}$ & $\begin{array}{l}23.6 \\
\pm 2.1 \\
b^{*}\end{array}$ & $\begin{array}{l}18.8 \\
\pm 1.6 \\
a\end{array}$ & $\begin{array}{l}27.4 \\
\pm 2.7 \\
a^{*}\end{array}$ \\
\hline 56 & $\begin{array}{l}7.9 \\
\pm 0.4 \\
a\end{array}$ & $\begin{array}{l}8.0 \\
\pm \\
0.5 \\
a\end{array}$ & $\begin{array}{l}5.2 \\
\pm \\
0.4 \\
b\end{array}$ & $\begin{array}{l}7.0 \\
\pm \\
0.4 \\
a^{*}\end{array}$ & $\begin{array}{l}5.4 \\
\pm \\
0.3 \\
b\end{array}$ & $\begin{array}{l}7.3 \\
\pm \\
0.7 \\
a^{*}\end{array}$ & $\begin{array}{l}19.0 \\
\pm 1.6 \\
b\end{array}$ & $\begin{array}{l}35.1 \\
\pm 3.8 \\
a^{*}\end{array}$ & $\begin{array}{l}17.4 \\
\pm 1.5 \\
b\end{array}$ & $\begin{array}{l}28.5 \\
\pm 2.6 \\
b^{*}\end{array}$ & $\begin{array}{l}28.5 \\
\pm 2.7 \\
a^{*}\end{array}$ & $\begin{array}{l}25.4 \\
\pm 2.4 \\
\text { c }\end{array}$ \\
\hline 180 & $\begin{array}{l}9.1 \\
\pm 0.9 \\
a^{*}\end{array}$ & $\begin{array}{l}8.2 \\
\pm \\
0.4 \\
a\end{array}$ & $\begin{array}{l}7.8 \\
\pm \\
0.5 \\
b^{*}\end{array}$ & $\begin{array}{l}4.8 \\
\pm \\
0.2 \\
b\end{array}$ & $\begin{array}{l}5.9 \\
\pm \\
0.4 \\
c^{*}\end{array}$ & $\begin{array}{l}4.9 \\
\pm \\
0.4 \\
b\end{array}$ & $\begin{array}{l}16.5 \\
\pm 1.5 \\
b\end{array}$ & $\begin{array}{l}49.0 \\
\pm 5.0 \\
a^{*}\end{array}$ & $\begin{array}{l}18.0 \\
\pm 1.6 \\
b\end{array}$ & $\begin{array}{l}42.6 \\
\pm 4.3 \\
b^{*}\end{array}$ & $\begin{array}{l}23.2 \\
\pm 2.0 \\
a\end{array}$ & $\begin{array}{l}31.7 \\
\pm 3.0 \\
c^{\star}\end{array}$ \\
\hline 360 & $\begin{array}{l}8.6 \\
\pm 0.7 \\
a\end{array}$ & $\begin{array}{l}8.2 \\
\pm \\
0.7 \\
a\end{array}$ & $\begin{array}{l}7.2 \\
\pm \\
0.6 \\
b^{*}\end{array}$ & $\begin{array}{l}4.8 \\
\pm \\
0.4 \\
b\end{array}$ & $\begin{array}{l}5.8 \\
\pm \\
0.4 \\
c^{*}\end{array}$ & $\begin{array}{l}4.9 \\
\pm \\
0.4 \\
\text { b }\end{array}$ & $\begin{array}{l}12.0 \\
\pm 1.0 \\
\mathrm{C}\end{array}$ & $\begin{array}{l}47.3 \\
\pm 4.0 \\
a^{*}\end{array}$ & $\begin{array}{l}17.0 \\
\pm 1.5 \\
\mathrm{~b}\end{array}$ & $\begin{array}{l}50.2 \\
\pm 5.0 \\
a^{*}\end{array}$ & $\begin{array}{l}20.5 \\
\pm 1.9 \\
a\end{array}$ & $\begin{array}{l}24.4 \\
\pm 2.2 \\
b^{*}\end{array}$ \\
\hline
\end{tabular}

${ }^{a}$ UF, unfertilized soil; OF, organic-fertilized soil.

${ }^{\mathrm{b}}$ Different lowercase letters show the significant differences $(P<0.05)$ between different residue treatments at the same incubation time.

${ }^{\mathrm{c}}$ Stars show the significant differences $(P<0.05)$ between different soil fertilization at the same residue treatment at the same incubation time. 
Soil fertilization and incubation time showed significant effects $(P<0.05)$ on MBC (Table 2 and Fig. 1c and d). MBC was initially $426 \mathrm{mg} \mathrm{kg}^{-1}$ and $280 \mathrm{mg} \mathrm{kg}^{-1}$ in the organic-fertilized soil and unfertilized soil, respectively (Fig. 1c and d), and then decreased by $85 \%$ at the end of incubation (on the 360th day). During the whole incubation, residue type had no significant effect $(P>0.05)$ on $\mathrm{MBC}$ in the unfertilized soil (Fig. 1c). The MBC of organic-fertilized soil treated with stem residue was higher than those of root and leaf residues in the first 28 days of incubation, then increased by $22 \% \sim 35 \%$ in the organic-fertilized soil treated with root residue compared with stem and leaf residues.

More $\mathrm{MBC}$ was derived from residue $\mathrm{C}\left({ }^{13} \mathrm{C}-\mathrm{MBC}\right)$ in the organic-fertilized soil than that in the unfertilized soil (Fig. 2c and d). The ${ }^{13} \mathrm{C}-\mathrm{MBC}$ treated with leaf residue was greater than those from root and stem residue $\mathrm{C}$ (except after 1 day) in the unfertilized soil. And the percentages of ${ }^{13} \mathrm{C}-\mathrm{MBC}$ ranged from $15-30 \%$ to the leaf residue, of which was $10-20 \%$ to the root and stem residues in the unfertilized soil (Table 3 ). The peaks of ${ }^{13} \mathrm{C}$ MBC values were 42,45 and $56 \mathrm{mg} \mathrm{kg}^{-1}$ soil on the 7th day, and then the second maximum values were 37,37 and $50 \mathrm{mg} \mathrm{kg}^{-1}$ soil occurred on the 56th day in the unfertilized soil treated with root, stem and leaf residues, respectively (Fig. 2c and d). The ${ }^{13} \mathrm{C}-\mathrm{MBC}$ contents of organic-fertilized soil decreased from $100 \mathrm{mg} \mathrm{kg}^{-1}$ soil on 1 st day to $25 \mathrm{mg} \mathrm{kg}^{-1}$ soil at the end of incubation. About $20 \% \sim 50 \%$ of $\mathrm{MBC}$ was derived from residue $\mathrm{C}$ in the organic-fertilized soil during the whole incubation, especially on the 180th day and 360th day, it exceeded to $40 \%$ (Table 3). In addition, the ${ }^{13} \mathrm{C}-\mathrm{MBC}$ contents derived from root residue was significantly greater $(P<0.05)$ than that derived from leaf residue after 28 days of incubation in the organic-fertilized soil. Even at the later incubation stage (on the 180th day and 360th day), MBC derived from root residue $\mathrm{C}$ was 4 times greater than that derived from leaf residue $\mathrm{C}$.

\section{Distribution of maize residue $\mathrm{C}$ in different soil $\mathrm{C}$ pools}

Overall, the distribution of root and stem derived C in EOC decreased with incubation time. In comparison, a peak distribution from leaf residue to EOC showed on the 28th day. At the end of incubation, the distribution of root-derived $\mathrm{C}$ in EOC was higher than those of stem and leaf derived $\mathrm{C}$ in both of unfertilized and organicfertilized soils treatments.

The distribution of maize residue $\mathrm{C}$ in $\mathrm{MBC}$ was higher in the organic-fertilized than that in the unfertilized soil treated with residues addition (Table 4). The two peak values in the distribution of residue $\mathrm{C}$ in $\mathrm{MBC}$ in the unfertilized were observed on the 7th day and 56th day, respectively (Table 4). However, the distribution of residue $\mathrm{C}$ in $\mathrm{MBC}$ decreased in the organic-fertilized soil during the whole incubation (Table 4). At the end of incubation, the distribution of leaf-derived $\mathrm{C}$ in $\mathrm{MBC}$ was higher than those of the stem and root-derived $\mathrm{C}$ in MBC in the unfertilized soil. However, in the organic-fertilized soil, less leaf-derived C was distributed to MBC compared with root and stem residues. 
Table 4

Distribution of residue carbon in extractable organic carbon and microbial biomass carbon (\%) in long-term fertilization of soils added with maize root, stem and leaf, respectively

\begin{tabular}{|c|c|c|c|c|c|c|c|c|c|c|c|c|}
\hline \multirow{3}{*}{$\begin{array}{l}\text { Incubation } \\
\text { time } \\
\text { (days) }\end{array}$} & \multicolumn{6}{|c|}{ Extractable organic carbon } & \multicolumn{6}{|c|}{ Microbial biomass carbon } \\
\hline & \multicolumn{2}{|c|}{$\begin{array}{l}\text { Root } \\
\text { residue }\end{array}$} & \multicolumn{2}{|c|}{$\begin{array}{l}\text { Stem } \\
\text { residue }\end{array}$} & \multicolumn{2}{|c|}{ Leaf residue } & \multicolumn{2}{|c|}{ Root residue } & \multicolumn{2}{|c|}{$\begin{array}{l}\text { Stem } \\
\text { residue }\end{array}$} & \multicolumn{2}{|c|}{ Leaf residue } \\
\hline & UF & OF & UF & OF & UF & OF & UF & OF & UF & OF & UF & OF \\
\hline
\end{tabular}

\begin{tabular}{|c|c|c|c|c|c|c|c|c|c|c|c|c|}
\hline 1 & $\begin{array}{l}5.7 \\
\pm \\
0.5\end{array}$ & $\begin{array}{l}4.4 \\
\pm \\
0.2\end{array}$ & $\begin{array}{l}6.0 \\
\pm \\
0.5\end{array}$ & $\begin{array}{l}4.9 \\
\pm \\
0.2\end{array}$ & $\begin{array}{l}4.0 \\
\pm 0.3\end{array}$ & $\begin{array}{l}3.3 \\
\pm \\
0.0\end{array}$ & $\begin{array}{l}7.0 \\
\pm 0.1\end{array}$ & $\begin{array}{l}18.1 \\
\pm 2.2 \\
b^{*}\end{array}$ & $\begin{array}{l}7.3 \\
\pm \\
0.1\end{array}$ & $\begin{array}{l}20.7 \\
\pm 2.1 \\
a^{*}\end{array}$ & $\begin{array}{l}8.0 \\
\pm 0.7 \\
a\end{array}$ & $\begin{array}{l}19.7 \\
\pm 1.9 \\
a b^{*}\end{array}$ \\
\hline 7 & $\begin{array}{l}2.9 \\
\pm \\
0.1 \\
b\end{array}$ & $\begin{array}{l}4.2 \\
\pm \\
0.3 \\
b^{*}\end{array}$ & $\begin{array}{l}3.9 \\
\pm \\
0.5\end{array}$ & $\begin{array}{l}4.5 \\
\pm \\
0.9 \\
\\
a^{*}\end{array}$ & $\begin{array}{l}2.8 \\
\pm 0.3 \\
b\end{array}$ & $\begin{array}{l}3.6 \\
\pm \\
0.3 \\
c^{*}\end{array}$ & $\begin{array}{l}8.7 \\
\pm 0.1 \\
\text { b }\end{array}$ & $\begin{array}{l}18.7 \\
\pm 1.2 \\
a^{*}\end{array}$ & $\begin{array}{l}8.5 \\
\pm \\
0.3 \\
b\end{array}$ & $\begin{array}{l}13.6 \\
\pm 1.3 \\
b^{*}\end{array}$ & $\begin{array}{l}11.1 \\
\pm 0.6 \\
a\end{array}$ & $\begin{array}{l}18.2 \\
\pm 1.1 \\
a^{*}\end{array}$ \\
\hline 28 & $\begin{array}{l}2.8 \\
\pm \\
0.1 \\
a\end{array}$ & $\begin{array}{l}4.8 \\
\pm \\
0.2 \\
b^{*}\end{array}$ & $\begin{array}{l}2.2 \\
\pm \\
0.2 \\
b\end{array}$ & $\begin{array}{l}4.8 \\
\pm \\
1.0 \\
b^{*}\end{array}$ & $\begin{array}{l}3.1 \\
\pm 0.7 \\
a\end{array}$ & $\begin{array}{l}5.5 \\
\pm \\
0.5 \\
a^{*}\end{array}$ & $\begin{array}{l}5.9 \\
\pm 0.4 \\
\text { b }\end{array}$ & $\begin{array}{l}17.2 \\
\pm 0.4 \\
a^{*}\end{array}$ & $\begin{array}{l}5.8 \\
\pm \\
0.7 \\
\text { b }\end{array}$ & $\begin{array}{l}12.7 \\
\pm 0.8 \\
b^{*}\end{array}$ & $\begin{array}{l}7.8 \\
\pm 0.4 \\
a\end{array}$ & $\begin{array}{l}10.6 \\
\pm 0.2 \\
c^{*}\end{array}$ \\
\hline 56 & $\begin{array}{l}2.7 \\
\pm \\
0.2 \\
a\end{array}$ & $\begin{array}{l}4.4 \\
\pm \\
0.8 \\
\\
a^{*}\end{array}$ & $\begin{array}{l}1.9 \\
\pm \\
0.2 \\
b\end{array}$ & $\begin{array}{l}3.3 \\
\pm \\
0.2 \\
\\
c^{*}\end{array}$ & $\begin{array}{l}2.2 \\
\pm 0.2 \\
b\end{array}$ & $\begin{array}{l}3.8 \\
\pm \\
0.2 \\
\mathrm{~b}^{*}\end{array}$ & $\begin{array}{l}7.7 \\
\pm 0.6 \\
b\end{array}$ & $\begin{array}{l}14.5 \\
\pm 1.4 \\
a^{*}\end{array}$ & $\begin{array}{l}7.1 \\
\pm \\
0.4 \\
b\end{array}$ & $\begin{array}{l}11.4 \\
\pm 0.7 \\
\mathrm{~b}^{*}\end{array}$ & $\begin{array}{l}11.2 \\
\pm 1.3 \\
a^{*}\end{array}$ & $\begin{array}{l}10.6 \\
\pm 0.4 \\
\text { b }\end{array}$ \\
\hline 180 & $\begin{array}{l}2.7 \\
\pm \\
0.1 \\
a\end{array}$ & $\begin{array}{l}3.8 \\
\pm \\
0.1 \\
\\
a^{*}\end{array}$ & $\begin{array}{l}2.8 \\
\pm \\
0.2 \\
\\
a^{*}\end{array}$ & $\begin{array}{l}1.8 \\
\pm \\
0.1 \\
b\end{array}$ & $\begin{array}{l}2.2 \\
\pm 0.1 \\
b\end{array}$ & $\begin{array}{l}2.1 \\
\pm \\
0.1 \\
b\end{array}$ & $\begin{array}{l}2.6 \\
\pm 0.0 \\
a\end{array}$ & $\begin{array}{l}10.0 \\
\pm 0.9 \\
a^{*}\end{array}$ & $\begin{array}{l}2.8 \\
\pm \\
0.2 \\
a\end{array}$ & $\begin{array}{l}7.1 \pm \\
0.3 \\
b^{*}\end{array}$ & $\begin{array}{l}2.9 \\
\pm 0.3 \\
a^{*}\end{array}$ & $\begin{array}{l}2.4 \\
\pm 0.7 \\
\mathrm{c}\end{array}$ \\
\hline 360 & $\begin{array}{l}2.8 \\
\pm \\
0.1 \\
a\end{array}$ & $\begin{array}{l}3.3 \\
\pm \\
0.2 \\
a^{*}\end{array}$ & $\begin{array}{l}2.3 \\
\pm \\
0.3 \\
\\
b^{*}\end{array}$ & $\begin{array}{l}1.5 \\
\pm \\
0.1 \\
b\end{array}$ & $\begin{array}{l}1.5 \\
\pm 0.0 \\
c\end{array}$ & $\begin{array}{l}1.7 \\
\pm \\
0.1 \\
b\end{array}$ & $\begin{array}{l}1.4 \\
\pm 0.1 \\
b\end{array}$ & $\begin{array}{l}6.9 \pm \\
1.1 \\
a^{*}\end{array}$ & $\begin{array}{l}1.6 \\
\pm \\
0.0 \\
b\end{array}$ & $\begin{array}{l}6.5 \pm \\
0.3 \\
a^{*}\end{array}$ & $\begin{array}{l}2.4 \\
\pm 0.1 \\
\mathrm{a}\end{array}$ & $\begin{array}{l}2.5 \\
\pm 0.1 \\
b\end{array}$ \\
\hline
\end{tabular}

a UF, unfertilized soil; OF, organic-fertilized soil. 
${ }^{\mathrm{b}}$ Different lowercase letters show the significant differences $(P<0.05)$ between different residue treatments at the same incubation time.

${ }^{c}$ Stars show the significant differences $(P<0.05)$ between different soil fertilization at the same residue treatment at the same incubation time.

\section{Discussion}

\section{Incorporation of residue $\mathrm{C}$ into EOC}

EOC and MBC are fractions of SOC that have rapid turnover rates and provide an easily accessible reservoir of $C$ and nutrients (Choudhary et al. 2013). Fresh residue $C$ addition can increase the content of EOC and MBC compared to soils with no residue addition because they provide $\mathrm{C}$ sources for soil microorganisms, and promote microbial growth (Jin et al. 2018; Perelo and Munch 2005). We found that more residue $\mathrm{C}$ was distributed in MBC (6.9\% and 13.8\%, in the unfertilized and organic-fertilized soil, respectively) compared with EOC (3.3\% and $3.5 \%$, in the unfertilized and organic-fertilized soils, respectively) for the whole residue amended treatments, which is consistent with previous results reported for this agricultural soil (An et al. 2015a). Although EOC in soil without newly-added residue represents a major bioavailable substrate for microorganisms (De Troyer et al. 2011), as there may be preferential assimilation of dissolved organic $C$ derived from residue $C$ with rapid consumption rates (Kuzyakov and Jones, 2006).

Soluble organic $\mathrm{C}$ is considered to be an important component for sequestering residue-derived $\mathrm{C}$ in soil (Choudhary et al. 2013). The EOC content in agricultural systems suggest that only a small portion of soluble organic $\mathrm{C}$ is derived from fresh plant residues (An et al. 2015a; Blagodatskaya et al. 2011a). We also found that only $1.5-2.3 \%$ of residue $\mathrm{C}$ remained in EOC for the all treatments after 1 year (Table 4). This is attributed to the fact that the soluble organics derived from newly-added residues are likely easily and preferentially degraded by microorganisms (Qiu et al 2015; Blagodatskaya et al. 2011b). As expected, a greater contribution of residue $\mathrm{C}$ to EOC was observed on the first day of incubation. The soluble organic fraction from fresh residue addition is released to soils after several hours or days, which implies relatively rapid EOC uptake by active microorganisms (De Troyer et al. 2011). Our first hypothesis assumed that more aboveground residue $\mathrm{C}$ would be incorporated in the labile organic $\mathrm{C}$. This was not confirmed at least in the EOC fraction regardless soil fertilization treatment (Fig. 2a and b). Some studies have found that SOM formation from root residue $\mathrm{C}$ inputs exceed those of the aboveground C inputs (e.g. stem and leaf residues) (Kong and Six. 2010). We observed a greater contribution of root-derived $\mathrm{C}$ in EOC fractions compared with stem and leaf residues (Fig. 2 and b, and Table 3). This suggest that root exudates from living plant biomass would have a strong potential for the formation of mineral-associated organic carbon (Sokol et al. 2019). Therefore, root-derived C stabilizes more efficiently than stem and leaf residues and highlight the important roles of roots in improving labile SOC pools in these agricultural soils. In addition, the mean residence time in soils for root-derived $\mathrm{C}$ has been found to be higher than stem-derived C (Rasse et al. 2005). This may be attributed to the chemical composition of residues (such as higher lignin in root residue) (Lian et al. 2016). The interaction of lignin molecules and transformed products of lignin with soil quality are important for SOC stability than their intrinsic chemical recalcitrance (Rasse et al. 2006). Therefore, the proportional incorporation of root-derived residue $C$ to the sequestration of EOC in the lab incubation of these agricultural soils was greater than that of aboveground residue C.

Page 11/19 
The second hypothesis assumed that soil fertilization would affect the distribution of residue $\mathrm{C}$ in EOC. Indeed, greater distribution of residue $\mathrm{C}$ in EOC fractions was observed in the unfertilized soil than that of organicfertilized soil. In addition, greater contribution of residue $C$ in EOC was observed in the unfertilized soil than that in the organic-fertilized soil at the end of incubation (Table 3). This may be because a proportionally greater amount of degradable $\mathrm{C}$ was input to unfertilized soil, and this added fresh $\mathrm{C}$ was assimilated rapidly by "starving" C-limiting microorganisms (Bastida et al. 2013; Chen et al. 2018). Fresh residue $C$ addition was easily assimilated as EOC by microorganisms in the unfertilized soil. In contrast, in the long-term organic manure application soil with more microbial biomass, the EOC derived from residue was preferentially used by microorganisms for energy production and was mostly released as $\mathrm{CO}_{2}$ (unpublished data), thus a lower incorporation of maize residue $\mathrm{C}$ into the EOC fraction was observed in the organic-fertilized soil.

\section{Incorporation of residue C into MBC}

The peak value of MBC derived from residue $\mathrm{C}$ occurred at different periods in different soil fertilization (Fig. 2c and d). This is consistent with the idea that residue availability is affected by initial nutrition and microbial activity of soils (An et al. 2015a; Chen et al. 2018). For example, the continuous decrease of the MBC derived from residue $\mathrm{C}$ in the organic-fertilized soil can be attributed to faster turnover by higher microbial activity (as $\mathrm{CO}_{2}$ released) in organic fertilizer treatment (unpublished). Microbial growth (and microbial biomass) depends on residue availability, which could be supported by the decrease of MBC after residue exhaustion (Shahbaz et al. 2017a). In contrast, due to the low SOC level in the unfertilized soil compared with the organic-fertilized soil, excess fresh residue $\mathrm{C}$ may induce the fluctuating change of $\mathrm{MBC}$ by the fast- ( $r$-strategist) and slow-growing ( $K$-strategist) microorganisms in soil (John et al. 2003; Fontaine et al. 2003), this may be a result of substrate metabolized by microorganisms shifts with changes the residue availability (Perelo and Munch 2005). Therefore, the dynamic changes of microbial biomass are affected by the fresh residue addition to the agricultural soils of long-term soil fertilization.

Contrary to our first hypothesis, we that more root-derived and stem-derived residue $\mathrm{C}$ was incorporated into MBC in the organic-fertilized soil, especially after 180 days of incubation (Table 3). The long-term application of organic manure not only increases soil fertility, but also alters soil microbial community and activity (Marschner et al. 2003). Maize stems could be preferentially utilized by microorganisms to incorporate into MBC because of their high carbohydrate concentrations (Clemente et al., 2013). Although root residue is observed to more slowly than stem and leaf residues (unpublished), root residue is still degraded and transformed to the stable SOC (Kuzyakov and Jones. 2006). It is possible that the portion of the microbial community utilizing more chemically complex $\mathrm{C}$ occupies a more dominant role in the organic-fertilized soil (Kiem and Kögel-Knabner 2013; Kramer and Gleixner 2006). Thus, more root and stem residues could be retained in organic-fertilized soil as stable SOC. In contrast, leaf residue contains a higher proportion of labile compounds (e.g. more sugar) that can be efficiently utilized by microorganisms, leading to larger microbial biomass than that from root- and stem-derived in previous studies, but only over the short-term (Cotrufo et al. 2013). In our study, more leaf-derived $C$ was distributed to $M B C$ compared with stem and root residues in the unfertilized soil (Table 4), as we hypothesised, which indicates that potentially greater substrate-use efficiency of leaf material. It is also possible that aboveground and belowground residues $\mathrm{C}$ are equally important to the formation of SOM, with their relative importance being driven by different environmental conditions (Sokol et al., 2019). For example, leaf litter leachate derived EOC contributes a major source of $C$ to mineral $C$ in forest 
ecosystems (Kaiser and Kalbitz. 2012). In addition, higher rates of transformation to SOM in leaf residue was observed in the $C$ poor soil than that of the $C$ rich soil (Miltner et al. 2012).

The contribution of residue $\mathrm{C}$ to $\mathrm{MBC}$ is not only related to residue types but also to soil fertilization levels (Shahbaz et al. 2017a). Our second hypothesis was not fully confirmed, at least in the MBC pool, as more distribution, and greater contribution, of residue $\mathrm{C}$ in $\mathrm{MBC}$ was observed in the organic-fertilized soil compared with the unfertilized soil (Tables 3 and 4). It has been widely observed that organic manure application markedly increases the MBC fraction (Gong et al. 2009; Ding et al. 2012). Long-term organic manure addition enhances the activity of microorganisms by providing a readily-available source of $C$ substrate (Li et al. 2018; Jin et al. 2018), thereby increasing the conversion of residue $C$ into MBC fraction. In addition, more residuederived MBC in fertilized soil has been found in some laboratory experiments (Jin et al. 2018; Lian et al. 2016). Conversely, excess fresh $\mathrm{C}$ input into unfertilized soil with the insufficient nitrogen and/or phosphorous (Table 1) might limit the residue availability for microbial growth. Organic manure treatment is thus a significant a significant control on the transformation of residue $C$ into microbial biomass as well as the stabilization of residue $\mathrm{C}$ in soil. Therefore, the residue-derived $\mathrm{C}$ contribution to $\mathrm{MBC}$ could be attributed with the initial soil $\mathrm{C}$ and nutrient background.

\section{Conclusion}

In summary, our results demonstrate that the incorporation of maize residue $\mathrm{C}$ into soil labile organic $\mathrm{C}$ pools (i.e., EOC and MBC) is strongly affected by residue type and soil fertilization. Specifically, root-derived C accumulated more in EOC and MBC than aboveground residue $C$ in the organic-fertilized soil, but leaf-derived $C$ accumulated more in $\mathrm{MBC}$ than those of root- and stem-derived $\mathrm{C}$ in the unfertilized soil, suggesting that root residue could lead to a greater potential labile $C$ pool, which could constitute the primary $C$ source for the microbial biomass and the precursor of stable SOC. This trend also indicates that the sequestration mechanisms of root $v s$. aboveground residues is regulated by soil fertilization, i.e., root-derived $\mathrm{C}$ may contribute more to stable SOC in the form of microbial products in the organic-fertilized soil, whereas leafderived $\mathrm{C}$ may be transformed into SOC more through the microbial synthesis in the unfertilized soil. Moreover, the contribution of residue $\mathrm{C}$ into EOC was greater in the unfertilized soil than that in the organic-fertilized soil, but more residue $\mathrm{C}$ was incorporated into $\mathrm{MBC}$ in the organic-fertilized soil than that in the unfertilized soil. This implies that the organic-fertilized soil should trigger a high $\mathrm{C}$ stabilization capacity following plant residue addition due to more microbial production, but the unfertilized soil was beneficial to promote the accumulation of plant residue in the form of EOC.

\section{Declarations}

\section{Acknowledgements}

This study is supported by the National Natural Science Foundation of China $(41977086,41701330$, 41771328). We are thankful to Shifeng Fu for technical support with the establishment of the experiment and elemental analyses. We also thankful to Jun Cui's suggestions of this original manuscript. Ninghui Xie would like to thank China Scholarship Council for the financial support from the visiting scholar program. We thank the anonymous reviewers for their helpful comments that significantly improved the manuscript.

Page 13/19 


\section{References}

1. Amelung W, Brodowski S, Sandhage-Hofmann A, Bol R (2008) Combining biomarker with stable isotope analyses for assessing the transformation and turnover of soil organic matter. Adv Agron 100:155-250.

2. An T, Schaeffer S, Zhuang J, Radosevich M, Li S, Li H, Pei J, Wang J (2015a) Dynamics and distribution of

${ }^{13} \mathrm{C}$-labeled straw carbon by microorganisms as affected by soil fertility levels in the Black Soil region of Northeast China. Biol Fertil Soils 51: 605-613.

3. An T, Schaeffer S, Li S, Fu S, Pei J, Li H, Zhuang J, Radosevich M, Wang J (2015b) Carbon fluxes from plant to soil and dynamics of microbial immobilization under plastic mulching and fertilizer application using ${ }^{13} \mathrm{C}$ pulse-labeling. Soil Biol Biochem 80: 53-61.

4. Bastida F, Torres IF, Hernández T, Bombach P, Richnow HH, García C (2013) Can the labile carbon contribute to carbon immobilization in semiarid soils? Priming effects and microbial community dynamics. Soil Biol Biochem 57: 892-902.

5. Blagodatskaya E, Yuyukina T, Blagodatsky S, Kuzyakov Y (2011a) Turnover of soil organic matter and of microbial biomass under $\mathrm{C} 3$ and $\mathrm{C} 4$ vegetation change: consideration of ${ }^{13} \mathrm{C}$ fractionation and preferential substrate utilization. Soil Biol Biochem 43: 159-166.

6. Blagodatskaya E, Yuyukina T, Blagodatsky S, Kuzyakov Y (2011b) Three-source-partitioning of microbial biomass and of $\mathrm{CO}_{2}$ efflux from soil to evaluate mechanisms of priming effects. Soil Biol Biochem 43:778-786.

7. Blaud A, Lerch TZ, Chevallie, Nunan N, Chenu C, Brauman A (2012) Dynamics of bacterial communities in relation to soil aggregate formation during the decomposition of ${ }^{13} \mathrm{C}$-labelled rice straw. Appl Soil Ecol 53: 1-9.

8. Burns R G, DeFores J, Marxsen, Sinsabaugh RL, Stromberger ME, Wallenstein MD, Weintrau N, Zoppin A (2013) Soil enzymes in a changing environment: current knowledge and future directions. Soil Biol Biochem 58: 216-34.

9. Chen Q, Ho R, Gong Y, Li H, Fan M, Kuzyakov Y (2009) Effects of 11 years of conservation tillage on soil organic matter fractions in wheat monoculture in Loess Plateau of China. Soil Till Res 106: 85-94.

10. Chen X, Li, Kuzyakov Y, Li W, Liu J, Jiang C, Wu M, Li P (2018) Incorporation of rice straw carbon into dissolved organic matter and microbial biomass along a 100-year paddy soil chronosequence. Appl Soil Ecol 130: 84-90.

11. Choudhary O, Gill JK (2013) Water-extractable carbon pools and microbial biomass carbon in sodic waterirrigated soils amended with gypsum and organic manures. Pedosphere 23: 88-97.

12. Clemente, J.S., Simpson, M.J., Simpson, A.J., Yanni, S.F. and Whalen, J.K., 2013. Comparison of soil organic matter composition after incubation with maize leaves, roots, and stems. Geoderma, 192, 86-96.

13. Cotrufo MF, Wallenstein M, Boo, Denef K, Pau E (2013) The Microbial Efficiency-Matrix Stabilization (MEMS) framework integrates plant litter decomposition with soil organic matter stabilization: do labile plant inputs form stable soil organic matter? Glob Chang Biol 19: 988-995.

14. Cotrufo MF, Soong JL, Horton J, Campbell EE, Haddix, Wall DH, Parton WJ (2015) Formation of soil organic matter via biochemical and physical pathways of litter mass loss. Nat Geosci 8: 776-779. 
15. De Troyer, Amery F, Van Moorleghe C, Smolders R, Merckx R (2011) Tracing the source and fate of dissolved organic matter in soil after incorporation of ${ }^{13} \mathrm{C}$ labelled residue: $\mathrm{A}$ batch incubation study. Soil Biol Biochem 43: 513-519.

16. Diacono M, Montemurro F (2010) Long-term effects of organic amendments on soil fertility. A review. Agron Sustain Dev 30: 401-422.

17. Ding X, Han X, Lian Y, Qiao, Li L, Li N (2012) Changes in soil organic carbon pools after 10 years of continuous manuring combined with chemical fertilizer in a Mollisol in China. Soil Tillage Res 122: 36-41.

18. Don A, Kalbitz K (2005) Amounts and degradability of dissolved organic carbon from foliar litter at different decomposition stages. Soil Biol Biochem 37: 2171-2179.

19. Fang Y, Singh B, Collins D, Li, Zhu J, Tavakkoli E (2018) Nutrient supply enhanced wheat residue-carbon mineralization, microbial growth, and microbial carbon-use efficiency when residues were supplied at high rate in contrasting soils. Soil Biol Biochem 126: 168-178.

20. Fontaine S, Mariott A, Abbadi L (2003) The priming effect of organic matter: a question of microbial competition? Soil Biol Biochem 35: 837-843.

21. Ge T, Liu C, Yuan H, Zhao Z, Wu X, Zhu Z, Brookes P, Wu J (2015) Tracking the photosynthesized carbon input into soil organic carbon pools in a rice soil fertilized with nitrogen. Plant Soil 392:17-25

22. Gong W, Ya X, Wang J, Hu, Gong (2009) Long-term manuring and fertilization effects on soil organic carbon pools under a wheat-maize cropping system in North China Plain. Plant Soil 314: 67-76.

23. Haubensak KA, Hart SC, Stark JM (2002) Influences of chloroform exposure time and soil water content on $\mathrm{C}$ and $\mathrm{N}$ release in forest soils. Soil Biol Biochem 34: 1549-1562.

24. Jin X, An T, Gall AR, Li S, Filly T, Wang J (2018) Enhanced conversion of newly-added maize straw to soil microbial biomass $\mathrm{C}$ under plastic film mulching and organic manure management. Geoderma 313: 154162.

25. John B, Ludwig B, Flessa H (2003) Carbon dynamics determined by natural C-13 abundance in microcosm experiments with soils from long-term maize and rye monocultures. Soil Biol Biochem 35: 1193-1202.

26. Johnson JMF, Nova JM, Varvel G, Stot DE, Osborne SL, Karlen DL, Lamb JA, Baker J, Adler PR (2014) Crop residue mass needed to maintain soil organic carbon levels: can it be determined? Bioenerg Res 7: 481490.

27. Kaiser, K., \& Kalbitz, K. (2012). Cycling downwards-dissolved organic matter in soils. Soil Biol Biochem 52, 29-32.

28. Kiem R, Kögel-Knabner I (2003) Contribution of lignin and polysaccharides to the refractory carbon pool in C-depleted arable soils. Soil Biol Biochem 35: 101-118.

29. Kong, A.Y. and Six, J., 2010. Tracing root vs. residue carbon into soils from conventional and alternative cropping systems. Soil Sci Soc Am J, 74, 1201-1210.

30. Kramer C, Gleixne G (2006) Variable use of plant- and soil-derived carbon by microorganisms in agricultural soils. Soil Biol Biochem 38: 3267-3278.

31. Kuzyakov Y, Jones DL (2006) Glucose uptake by maize roots and its transformation in the rhizosphere. Soil Biol Biochem 38: 851-860. 
32. Lal R (2004) Soil carbon sequestration impacts on global climate change and food security. Science 304 : 1623-1627.

33. Lehmann J, Kleber M (2015) The contentious nature of soil organic matter. Nature 528: 60-68.

34. Li J, Wen Y, Li X, Li Y, Yang X, Lin Z, Song Z, Cooper JM, Zhao B (2018) Soil labile organic carbon fractions and soil organic carbon stocks as affected by long-term organic and mineral fertilization regimes in the North China Plain. Soil Tillage Res 175: 281-290.

35. Lian T, Wang G, Yu Z, Li Y, Liu B, Jin J (2016) Carbon input from ${ }^{13} \mathrm{C}$-labelled soybean residues in particulate organic carbon fractions in a Mollisol. Biol Fertil Soils 52: 331-339.

36. Liang, C., Schimel, J.P. and Jastrow, J.D., 2017. The importance of anabolism in microbial control over soil carbon storage. Nat. microbiol. 2, 1-6.

37. Macci C, Doni S, Peruzzi E, Mennone C, Masciandaro G (2013) Biostimulation of soil microbial activity through organic fertilizer and almond tree association. Land Degrad Dev 27: 335-345.

38. Marschner P, Yang C, Lieberei R, Crowley DE (2001) Soil and plant specific effects on bacterial community composition in the rhizosphere. Soil Biol Biochem 33: 1437-1445.

39. Marschner P, Kandeler E, Marschner B (2003) Structure and function of the soil microbial community in a long-term fertilizer experiment. Soil Biol Bioche 35: 453-461.

40. Marschner P, Hatam Z, Cavagnaro TR (2015) Soil respiration, microbial biomass and nutrient availability after the second amendment are influenced by legacy effects of prior residue addition. Soil Biol Biochem 88: $169-177$.

41. Miltner A, Bombach P, Schmidt-Brücken B, Kästner M (2012) SOM genesis: microbial biomass as a significant source. Biogeochemistry 111: 41-55.

42. Moore JM, Klose S, Tabatabai MA (2000) Soil microbial biomass carbon and nitrogen as affected by cropping systems. Biol Fertil Soils 31: 200-210.

43. Nieder R, Harden T, Martens R, Benbi DK (2008) Microbial biomass in arable soils of Germany during the growth period of annual crops. J Plant Nutr Soil Sci 171: 878-885.

44. Paustian K, Six J, Elliott ET, Hunt HW (2000) Management options for reducing $\mathrm{CO} 2$ emissions from agricultural soils. Biogeochemistry 48: 147-

45. Perelo LW, Munch JC (2005) Microbial immobilisation and turnover of ${ }^{1} 3 \mathrm{C}$ labelled substrates in two arable soils under field and laboratory conditions. Soil Biol Biochem 37: 2263-2272.

46. Prescott CE (2010) Litter decomposition: what controls it and how can we alter it to sequester more carbon in forest soils? Biogeochemistry 101: 133-149.

47. Qiu Q, Wu L, Ouyang Z, Li B, Xu Y, Wu S, Gregorich EG (2016) Priming effect of maize residue and urea N on soil organic matter changes with time. Appli Soil Ecol 100: 65-74.

48. Rasse DP, Rumpel C, Dignac MF (2005) Is soil carbon mostly root carbon? Mechanisms for a specific stabilisation. Plant Soil 269: 341-356

49. Rasse DP, Dignac MF, Bahri H, Bahri C, Rumpel A, Mariotti CC (2006) Lignin turnover in an agricultural field: from plant residues to soilprotected fractions. Eur J Soil Sci 57:530-538

50. Salinas-Garcia JR, Hons FM, Matocha JE (1997) Long-term effects of tillage and fertilization on soil organic matter dynamics. Soil Sci Soc Am J 61: 152-159 
51. Schaeffer SM, Sharp E, Schimel JP, Welker JM (2013) Soil-plant N processes in a High Arctic ecosystem, NW Greenland are altered by long-term experimental warming and higher rainfall. Glob Chang Biol 19: 3529-3539.

52. Schmidt MW, Torn MS, Abiven S, Dittma T, Guggenberger G, Janssens IA, Klebe M, Kögel-Knabner I, Lehmann J, Manning DA, Nannipieri P (2011) Persistence of soil organic matter as an ecosystem property. Nature 478: 49-56.

53. Shahbaz M, Kuzyakov Y, Sanaullah M, Heitkamp F, Zelenev V, Kumar A, Blagodatskaya E (2017a) Microbial decomposition of soil organic matter is mediated by quality and quantity of crop residues: mechanisms and thresholds. Biol Fertil Soils 53: 287-301.

54. Shahbaz M, Kuzyakov Y, Heitkamp F (2017b) Decrease of soil organic matter stabilization with increasing inputs: Mechanisms and controls. Geoderma 304: 76-82.

55. Silveira ML, Comerford NB, Reddy KR, Cooper WT, El-Rifai H (2008) Characterization of soil organic carbon pools by acid hydrolysis. Geoderma 144: 405-414

56. Singh S, Ghoshal N, Singh KP (2007) Variations in soil microbial biomass and crop roots due to differing resource quality inputs in a tropical dryland agroecosystem. Soil Biol Biochem 39: 76-86.

57. Sokol, N.W., Sanderman, J. and Bradford, M.A (2019) Pathways of mineral-associated soil organic matter formation: Integrating the role of plant carbon source, chemistry, and point of entry. Glob Chang Biol 25, $12-24$.

58. Soil Survey Staff (1999) Soil Taxonomy: a Basic System of Soil Classification for Making and Interpreting Soil Surveys, second ed. Natural Resources Conservation Services and USDA, Washington DC, USA.

59. Vance ED, Brookes PC, Jenkinson DS (1987) An extraction method for measuring soil microbial biomass C. Soil Biol Biochem 19: 703-707.

60. Wang Q, Wang S, He T, Liu L, Wu J (2014) Response of organic carbon mineralization and microbial community to leaf litter and nutrient additions in subtropical forest soils. Soil Biol Biochem 71: 13-20.

61. Werner RA, Brand WA (2001) Referencing strategies and techniques in stable isotope ratio analysis. Rapid Commun Mass Sp 15: 501-519.

62. Wu J, Joergensen RG, Pommerening B, Chausso R, Brooke PC (1990) Measurement of soil microbial biomass $\mathrm{C}$ by fumigation-extraction-an automated procedure. Soil Biol Biochem 22: 1167-1169.

63. Zhu Z, Ge T, Xiao M, Yuan H, Wang T, Liu S, Atere CT, Wu J, Kuzyakov Y (2017) Belowground carbon allocation and dynamics under rice cultivation depends on soil organic matter content. Plant Soil 410: 24758.

\section{Figures}



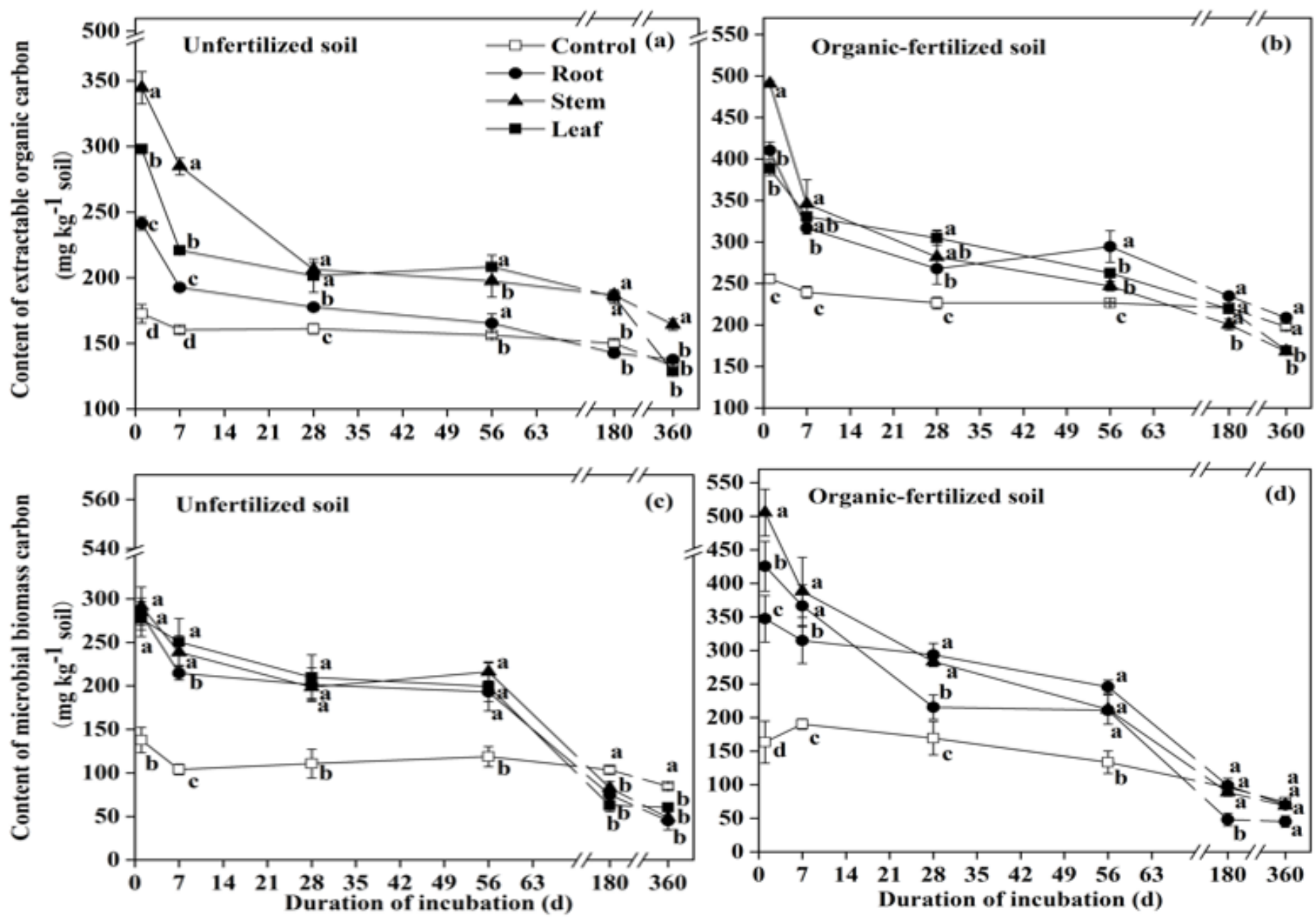

\section{Figure 1}

The contents of extractable organic carbon ( $a$ and $b$ ) and microbial biomass carbon ( $c$ and $d$ ) in different soil fertilization added with 13C-labeled maize root, stem and leaf residues, respectively. Different lowercase letters show the significant differences $(P<0.05)$ between different treatments at the same incubation time. 

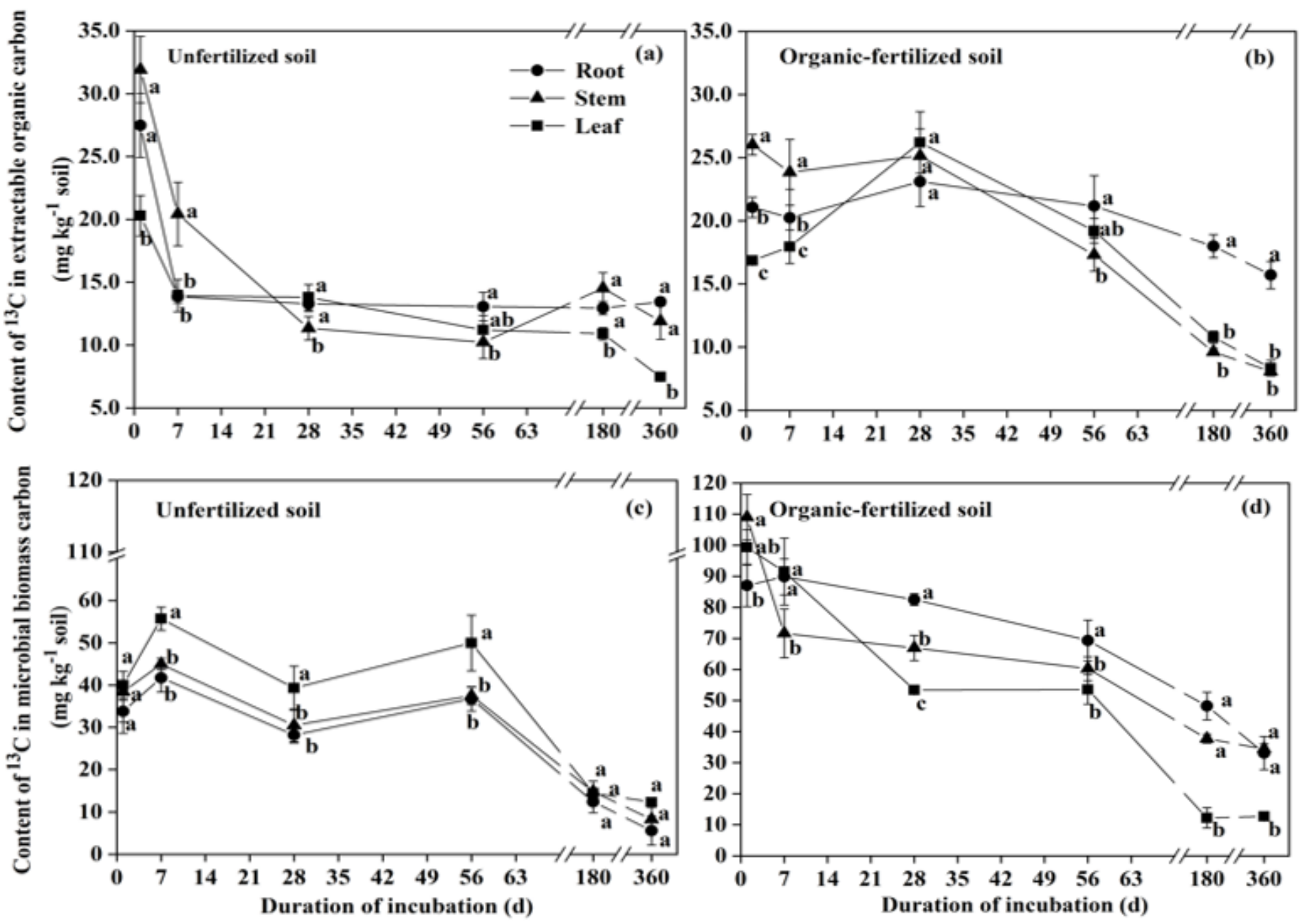

\section{Figure 2}

The $13 \mathrm{C}$ contents of extractable organic carbon ( $a$ and b) and microbial biomass carbon ( $c$ and $d)$ derived from residue carbon in different fertility level soils added with 13C-labeled maize root, stem and leaf residues, respectively. Different lowercase letters show the significant differences $(P<0.05)$ between different treatments at the same incubation time. 